\title{
New species of Aberrapex Jensen, 2001 (Cestoda: Lecanicephalidea) from eagle rays of the genus Myliobatis Cuvier (Myliobatiformes: Myliobatidae) from off Argentina
}

\author{
Adriana Menoret ${ }^{1,2, *}$, Leonardo Mutti ${ }^{1,2, *}$ and Verónica A. Ivanov ${ }^{1,2,3}$ \\ ${ }^{1}$ Instituto de Biodiversidad y Biología Experimental y Aplicada (IBBEA, CONICET-UBA), Facultad de Ciencias Exactas y \\ Naturales, Universidad de Buenos Aires, Ciudad Autónoma de Buenos Aires, Argentina; \\ ${ }^{2}$ Consejo Nacional de Investigaciones Científicas y Técnicas, Argentina; \\ ${ }^{3}$ Departamento de Biodiversidad y Biología Experimental, Facultad de Ciencias Exactas y Naturales, Universidad de Buenos Aires, \\ Ciudad Autónoma de Buenos Aires, Argentina \\ ${ }^{*}$ These author contributed on the work equally.
}

\begin{abstract}
Three new species of Aberrapex Jensen, 2001 (Cestoda: Lecanicephalidea) have been collected from species of Myliobatis Cuvier along the coast of Argentina. Aberrapex ludmilae sp. n. parasitises M. goodei Garman in the San Matías Gulf. This species is unique in a combination of features including the shape and extent of the uterus, scolex size, testis distribution, and by lacking an external seminal vesicle and postovarian vitelline follicles. Aberrapex sanmartini sp. n. from M. goodei in San Blas Bay and A. vitalemuttiorum sp. n. from M. ridens Ruocco, Lucifora, Díaz de Astarloa, Mabragaña et Delpiani in coastal waters off Buenos Aires Province, are distinguished from all other congeners by the microthrix pattern on the scolex surface, uterus shape and extension, position of the connection of the uterine duct to the uterus, presence and extension of an external seminal vesicle, and its overall size and number of proglottids. The specimens of $M$. goodei and M. ridens show locally distinct cestode faunas, which are correlated with well-defined biogeographic regions. Some of these areas correspond with mating and nursery zones for species of Myliobatis.
\end{abstract}

Keywords: tapeworms, Aberrapex ludmilae, Aberrapex sanmartini, Aberrapex vitalemuttiorum, Myliobatis goodei, Myliobatis ridens

Lecanicephalidean cestodes are parasites of elasmobranchs, distributed worldwide, particularly in warmer coastal waters (i.e. between latitudes of $40^{\circ} \mathrm{N}$ and $40^{\circ} \mathrm{S}$ ) (Caira and Jensen 2014). At the southern limit of their distribution in the western Atlantic Ocean, only two species have been reported, Aberrapex arrhynchus (Brooks, Mayes et Thorson, 1981) from Myliobatis goodei Garman and Paraberrapex atlanticus Mutti et Ivanov, 2016 from Squatina guggenheim Marini (see Brooks et al. 1981, Jensen 2001, Mutti and Ivanov 2016). Aberrapex arrhynchus was originally described as Discobothrium arrhynchum Brooks, Mayes et Thorson, 1981. Jensen (2001) redescribed this species based on type specimens and transferred it to Aberrapex Jensen, 2001.

The four species currently valid in Aberrapex parasitise myliobatiform batoids of the genera Taeniura Müller et Henle, Aetomylaeus Garman and Myliobatis Cuvier from tropical and temperate waters (Jensen 2001, 2005, 2006, Koch et al. 2012). Among these host genera, only species of Myliobatis have been reported from Argentine waters (i.e. M. freminvillei Lesueur, M. goodei and M. ridens Ruocco, Lucifora, Díaz de Astarloa, Mabragaña et Delpiani; see Cousseau et al. 2010, Ruocco et al. 2012). The geographic distribution of $M$. goodei and M. freminvillei includes the coastal regions of the western Atlantic Ocean (essentially from North America to Argentina), whereas that of $M$. ridens is restricted to coastal regions off Brazil and Argentina (Cousseau et al. 2007). Only M. goodei has been previously reported as a host for tapeworms in the south-western Atlantic, being parasitised by at least seven species of cestodes of the orders Diphyllidea, Trypanorhyncha, Phyllobothriidea, Tetraphyllidea and Lecanicephalidea (see Brooks et al. 1981, Ivanov and Campbell 1998, Menoret and Ivanov 2014, 2015). Records of cestodes from M. freminvillei are restricted to a single species of Tetraphyllidea from the north-western Atlantic (Linton 1890).

Recent collections of tapeworms of $M$. goodei and M. ridens from different locations along the continental shelf off Argentina revealed the presence of three new species of Aberrapex, which are described herein. 


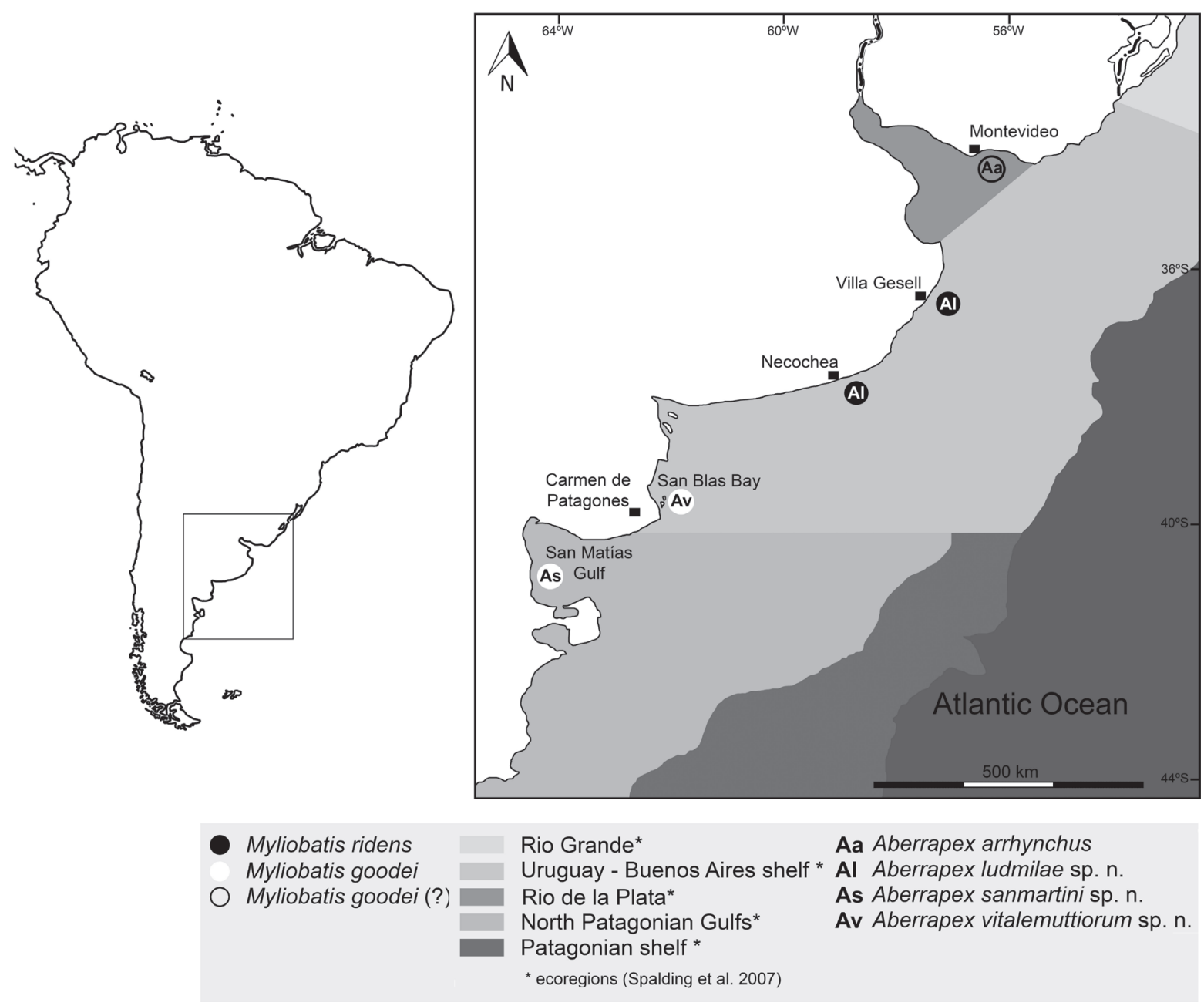

Fig. 1. Sample sites of myliobatid hosts and their respective species of Aberrapex Jensen, 2001 in the southwest Atlantic.

\section{MATERIALS AND METHODS}

Cestodes examined in the present study were recovered from the spiral intestines of three specimens of Myliobatis goodei and two specimens of $M$. ridens were caught at the following localities along the coast of Argentina (Fig. 1): one specimen of M. goodei caught in December 1999 in the San Matías Gulf, Río Negro Province ( $40^{\circ} 58^{\prime} 00^{\prime \prime} \mathrm{S}$; $\left.64^{\circ} 56^{\prime} 00^{\prime \prime} \mathrm{W}\right)$ by commercial trawlers (host field number SAO-1), and two specimens of $M$. goodei caught in April 2013 in San Blas Bay off Carmen de Patagones, Buenos Aires Province (4042'58"S; 62 $\left.02^{\circ} 35^{\prime \prime} \mathrm{W}\right)$ with bottom trawls on board of the Oceanographic Vessel 'Puerto Deseado' (CONICET) (host field numbers PD7-512b, PD7-514, respectively). One specimen of M. ridens was caught in August 2012 off Villa Gesell, Buenos Aires Province (3729'30"S; 56²45'00"W) also with bottom trawls on board of the Oceanographic Vessel 'Puerto Deseado' (host field number PD5-011), and one specimen was caught in December 2015 off Punta Negra, Necochea, Buenos Aires Province (38³7'59"S; 58 51'58"W) using rod and reel (host field number FMPQ-76). Additional six specimens of $M$. goodei were also examined but no lecanicephalidean cestodes were recovered from them. Three of them were caught in October 2002 off Mar del Plata, Buenos Aires Province (3800'30"S; $\left.57^{\circ} 33^{\prime} 00^{\prime \prime} \mathrm{W}\right)$, and three specimens caught in July 2001 and January 2011 off Puerto Quequén, Buenos Aires Province (38³7'30"S; $\left.58^{\circ} 53^{\prime} 00^{\prime \prime} \mathrm{W}\right)$ by commercial trawlers.
All tapeworms were removed from the spiral intestine of their respective host, fixed in $4 \%$ formalin and transferred to $70 \%$ ethanol for storage. The specimens prepared for light microscopy were hydrated in a graded ethanol series, stained with Harris' haematoxylin, dehydrated in a graded ethanol series, cleared in methyl salicylate and mounted in Canada balsam. Worms prepared for scanning electron microscopy (SEM) were hydrated in a graded ethanol series, post-fixed in $1 \%$ osmium tetroxide overnight at room temperature, dehydrated in a graded ethanol series, and dried using hexamethyldisilazane. After dehydration, the specimens were mounted on stubs with carbon tape, coated with $c a 40 \mathrm{~nm}$ of gold/palladium in a Thermo VG Scientific Polaron SC 7630 and examined in a Philips XL 30 scanning electron microscope. Detached mature proglottids were embedded in paraffin and serial cross-sections were cut at a thickness of $8 \mu \mathrm{m}$. Sections were stained with Harris' haematoxylin, counterstained with eosin and mounted in Canada balsam. Gravid proglottids were opened with insect pins to release the cocoons. Cocoons were mounted in lactophenol and sealed with nail polish. Whole mounts and sections were observed and measured using an Olympus BX51 compound microscope. Drawings were made with the aid of a drawing tube. Measurements include the range, followed in parentheses by the mean, standard deviation, number of worms examined, and the total number of observations when more than one measurement per worm was taken. All measurements are in 

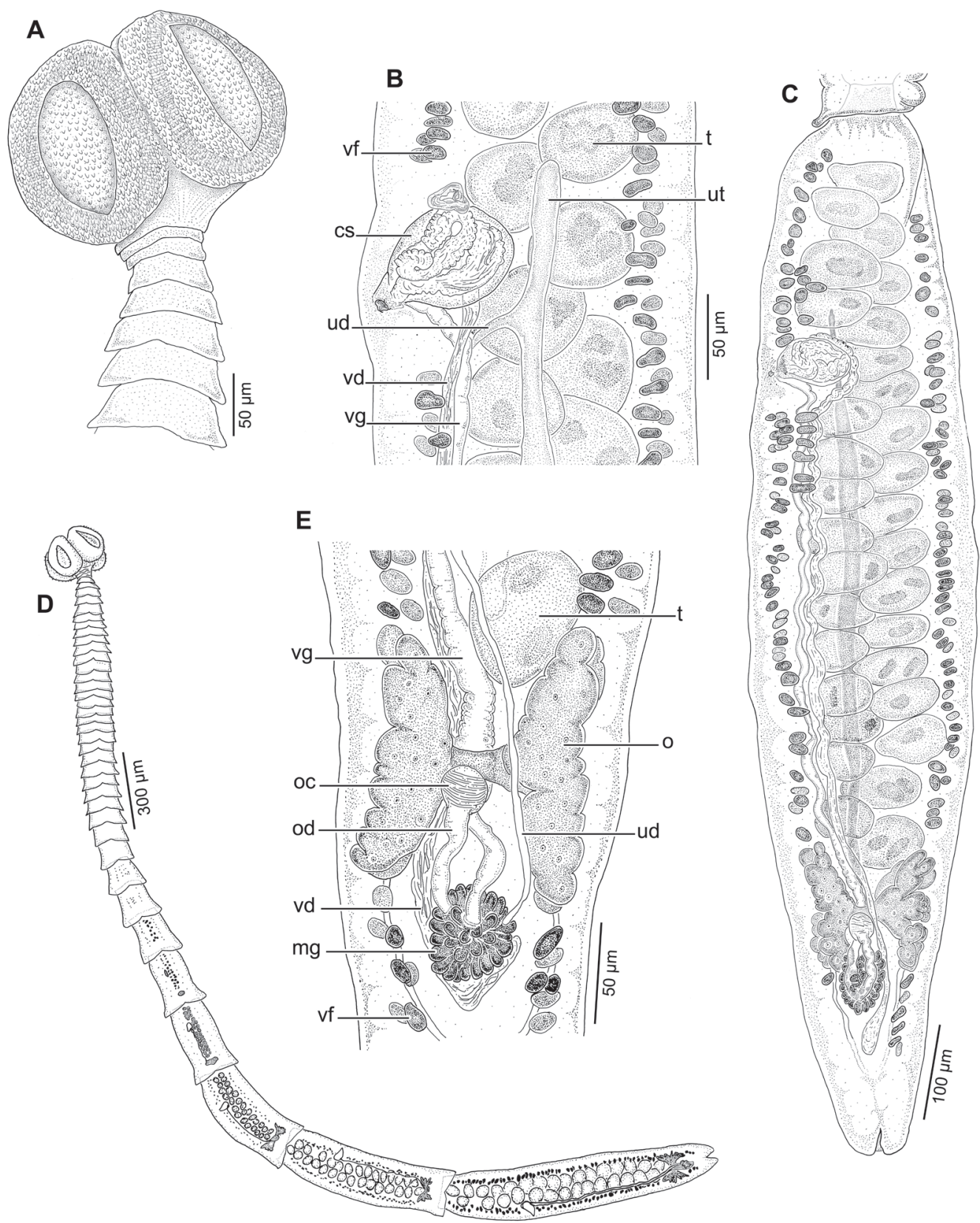

Fig. 2. Aberrapex ludmilae sp. n. from Myliobatis goodei Garman. A - scolex (paratype MACN-Pa No. 616/2); B - detail of terminal genitalia, ventral view (holotype MACN-Pa No. 616/1); C - terminal mature proglottid, dorsal view (paratype IPCAS No. C-755); D - entire worm (paratype MACN-Pa No. 616/2); E - detail of ootype region, ventral view (holotype MACN-Pa No. 616/1). Abbreviations: cs - cirrus sac; mg - Mehlis' gland; o- ovary; oc-ovicapt; od - oviduct; $\mathrm{t}$ - testis; ud - uteroduct; ut - uterus; vd - vas deferens; vf - vitelline follicle; vg - vagina.

micrometres unless otherwise stated. Terminology for microthrix shape follows Chervy (2009). Shape terminology for cirrus sac follows Clopton (2004). Measurements for A. arrhynchus are based on the original description and observations made on 21 paratypes (USNPC No. 75723 and HWML No. 21003).

Museum abbreviations used are as follows: HWML, Harold W. Manter Laboratory of Parasitology, University of Nebraska, Lincoln, Nebraska, USA; IPCAS, Institute of Parasitology, Czech Academy of Sciences, České Budějovice, Czech Republic; LRP, Lawrence R. Penner Parasitology Collection, Department of Ecology and Evolutionary Biology, University of Connecticut, Storrs, Connecticut, USA; MACN-Pa, Museo Argentino de Ciencias Naturales, Colección Parasitológica, Buenos Aires, Ar- gentina; USPNC, Department of Invertebrate Zoology, National Museum of Natural History, Smithsonian Institution, Washington, D.C., USA.

\section{RESULTS}

Aberrapex ludmilae sp. $\mathbf{n}$.

Fig. 2

ZooBank number for species:

urn:1sid:zoobank.org:act:28BAA118-5659-4DE7-BE60-2749BB820095

Description (based on 9 specimens, all whole mounts of entire worms). Worms $3.33-4.93 \mathrm{~mm}$ (3.93 $\mathrm{mm} \pm$ 
$0.48 \mathrm{~mm}$; 9) long, maximum width at level of scolex or terminal proglottid, euapolytic, 37-45 (40 \pm 3 ; 9) proglottids per worm (Fig. 2D). Scolex 160-190 (168 \pm 8 ; 7) long, 210-255 (225 $\pm 15 ; 9)$ wide, consisting of 4 bothridiate acetabula; apical modification of scolex proper and apical organ absent (Fig. 2A). Acetabula cup-shaped, 145-170 (153 \pm 5 ; 9) long, 100-127 (109 \pm 6 ; 9) wide (Fig. 2A). Cephalic peduncle absent.

Proglottids laciniate, with 4 laciniations (2 dorsal, 2 ventral) (Fig. 2D). Immature proglottids 36-44 (39 \pm 3 ; 9) in number, initially wider than long, becoming longer than wide with maturity; posterior-most immature proglottid 460-800 (593 \pm 116 ; 9) long, 115-250 (182 \pm 41 ; 9) wide (Fig. 2D). Only 1 mature proglottid with testes per strobila, longer than wide, $810-1,137(927 \pm 134$; 9) long, 110-255 (202 \pm 44 ; 9) wide (Fig. 2C,D).

Testes 24-31 (28 $\pm 3 ; 8)$ in number, 25-57 (49 $\pm 11 ; 5$; 8) long, 33-80 (57 $\pm 14 ; 5 ; 13)$ wide, arranged in 2 columns in dorsoventral view, extending from anterior margin of proglottid to anterior margin of ovary, slightly overlapping aporal ovarian lobe anteriorly (Fig. 2C,D), 1 row deep in cross-section. Vas deferens in form of thin tube, extending from level of ootype to cirrus sac along lateral margin of proglottid, entering cirrus sac at its anteroproximal margin, not expanded to form external seminal vesicle. Internal seminal vesicle absent (Fig. 2B). Cirrus sac oval, slightly curved anteriorly in some specimens (Fig. 2B), 43-98 (70 $\pm 19 ; 7)$ long, 28-65 (43 $\pm 14 ; 7)$ wide, containing coiled unarmed cirrus.

Ovary $\mathrm{H}$-shaped in dorsoventral view, tetralobed in cross-section, lobulated, 70-160 (113 \pm 26 ; 7) long, 93-155 $(124 \pm 22 ; 7)$ wide; ovarian isthmus at middle of ovary (Fig. 2C,E). Mehlis' gland posterior to ovary (Fig. 2C,E). Vagina slender, extending from ootype to genital atrium laterally in proglottid, opening into genital atrium posterior to cirrus sac (Fig. 2C). Sublateral genital pores, irregularly alternating, $68-76 \%(71 \% \pm 3 \% ; 9)$ of proglottid length from posterior margin in mature proglottids.

Uterus saccate, extending along midline of proglottid from level of anterior margin of ovary to level of anterior margin of cirrus sac (Fig. 2B,C). Uterine duct extending anteriorly from ootype, laterally to vas deferens and vagina, entering uterus slightly posterior to level of genital pore (Fig. 2B); uterine pore absent. Vitelline follicles in 2 columns (1 dorsal, 1 ventral) on each lateral margin of proglottid, extending throughout entire proglottid, interrupted at level of cirrus sac and ovary (Fig. 2B,C,E); vitelline follicles $3-13(8 \pm 3 ; 5 ; 15)$ long, 3-38 (15 $\pm 8 ; 5 ; 15)$ wide. Eggs and excretory ducts not observed.

Type host: Myliobatis goodei Garman, southern eagle ray (Myliobatiformes: Myliobatidae).

Site of infection: Spiral intestine.

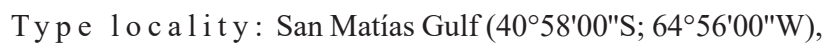
Río Negro Province, Argentina (Fig. 1).

Specimens deposited: Holotype MACN-Pa No 616/1 (entire worm) and 4 paratypes MACN-Pa No. 616/2-5 (entire worms); 2 paratypes IPCAS No. C-755/1-2 (entire worms); 1 paratype LRP No. 9239 (entire worm).
Prevalence: $11 \%$ (1 host infected out of 9 specimens examined).

Ety mology: This species is named after the second author's sister, Ludmila Antonella Mutti.

Remarks. This species belongs to the lecanicephalidean genus Aberrapex, because it has a scolex lacking both an apical modification of the scolex proper and an apical organ, a vagina that is positioned lateral in the proglottid and opens into genital atrium posterior to the cirrus sac, a tetralobed ovary in cross-section, a testicular field that begins at the anterior margin of the ovary, and the acetabular surfaces covered with hastate spinitriches (Jensen 2001, 2005, Jensen et al. 2016).

Aberrapex ludmilae sp. n. differs from A. manjajiae Jensen, 2006, A. senticosus Jensen, 2001 and A. weipaensis Koch, Jensen et Caira, 2012 in that the vas deferens is not expanding to form an external seminal vesicle. In addition, the uterus extends anteriorly to the anterior margin of the cirrus sac in $A$. ludmilae sp. n., whereas it only reaches the posterior margin of the cirrus sac in $A$. manjajiae and $A$. arrhynchus. Moreover, A. ludmilae sp. n. has postovarian vitelline follicles, which are lacking in A. weipaensis, and exhibits testes in two rather than in one column as seen in A. manjajiae. Finally, A. ludmilae sp. n. possesses a longer scolex than $A$. senticosus, A. manjajiae and A. weipaensis (160-190 $\mu \mathrm{m}$ long vs 100-130 $\mu \mathrm{m}, 82-101 \mu \mathrm{m}$ and 40-63 $\mu \mathrm{m}$ long, respectively).

\section{Aberrapex sanmartini sp. $\mathbf{n}$.}

Figs. 3, 4

ZooBank number for species:

urn:1sid:zoobank.org:act:ACFE2C11-84D2-4627-B920-561FD875CF66

Description (based on 19 specimens: 9 complete mature worms, 3 strobila without scoleces, 2 detached mature proglottids, 2 detached gravid proglottids and 3 worms prepared for SEM). Worms 1.12-2.39 mm (1.71 $\mathrm{mm} \pm$ $0.42 \mathrm{~mm}$; 9) long, maximum width at level of terminal proglottid, euapolytic, 26-30 $(28 \pm 1$; 9) proglottids per worm (Fig. 3D). Scolex 100-150 (128 \pm 17 ; 9) long, 155-250 $(204 \pm 34 ; 8)$ wide, consisting of 4 bothridiate acetabula; apical modification of scolex proper and apical organ absent (Figs. 3A,D, 4A,B). Acetabula cup-shaped, 100-138 $(117 \pm 14$; 9) long, 73-120 (99 \pm 16 ; 9) wide (Figs. 3A,D, 4A,B). Apex of scolex (Fig. 4C) covered with acicular filitriches. Proximal and distal acetabular surface covered with hastate spinitriches and acicular filitriches (Fig. 4B,D,E); hastate spinitriches only covering anterior $2 / 3$ of distal acetabular surface (Fig. 4B). Cephalic peduncle absent.

Proglottids covered with capilliform filitriches (Fig. 4F). Proglottids laciniate, with 4 laciniations (2 dorsal, 2 ventral), less evident in mature proglottids (Fig. 3A,B,D). Immature proglottids $24-28(26 \pm 2 ; 9)$ in number, initially wider than long, becoming longer than wide with maturity; posterior-most immature proglottid 110-240 (151 \pm 37 ; 11) long, $140-220(180 \pm 22$; 11) wide. Mature proglottids $1-2$ in number, terminal mature proglottids with tes- 

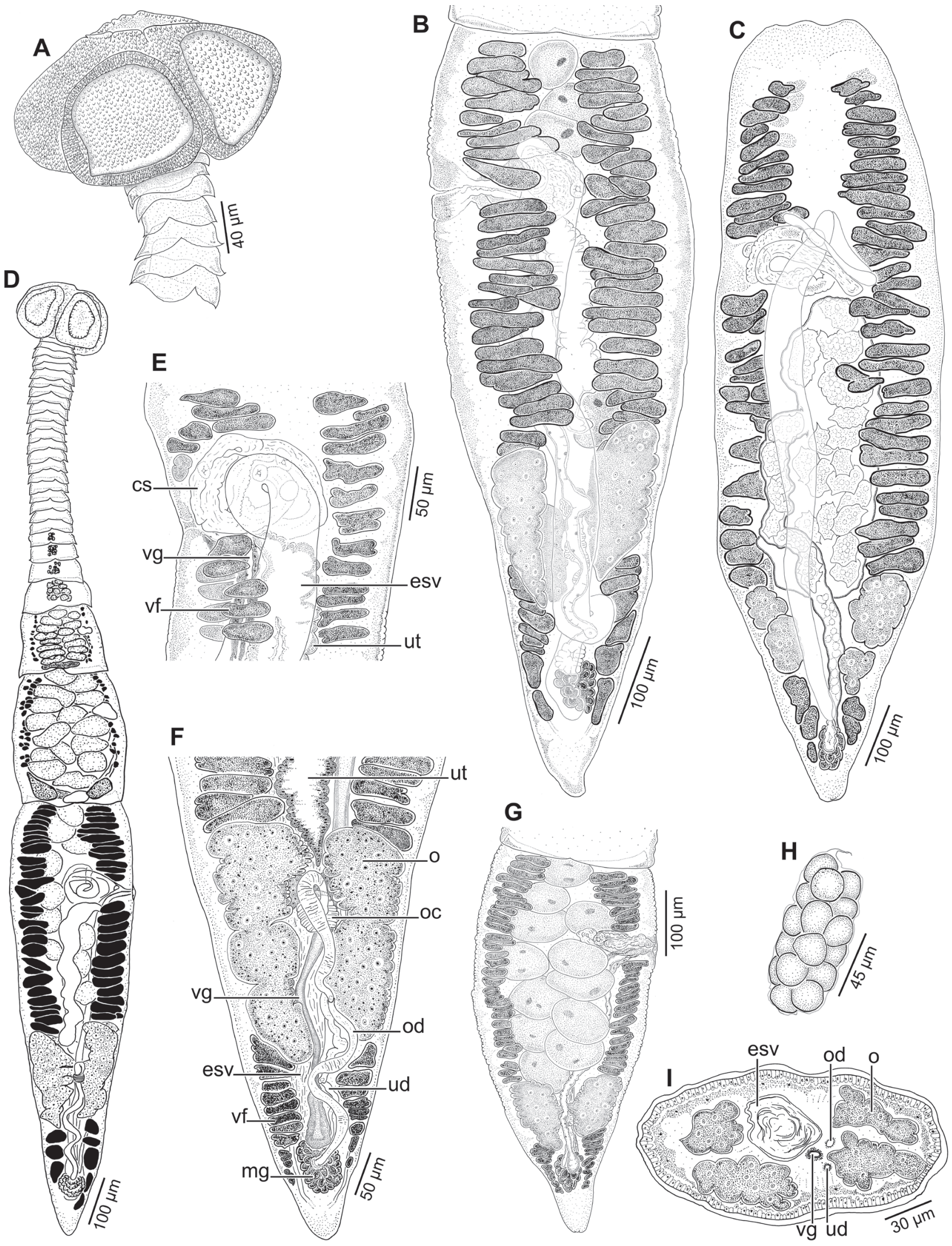

Fig. 3. Aberrapex sanmartini sp. n. from Myliobatis goodei Garman. A-scolex (paratype MACN-Pa No. 617/2); B - terminal mature proglottid with degenerated testes, dorsal view (paratype MACN-Pa No. 617/3); C - detached gravid proglottid, dorsal view (paratype MACN-Pa No. 617/4); D - entire worm (holotype MACN-Pa No. 617/1); E - detail of terminal genitalia, dorsal view (paratype MACN-Pa No. 617/5); F - detail of ootype region, ventral view (paratype MACN-Pa No. 617/6); G - terminal mature proglottid with testes, ventral view (paratype MACN-Pa No. 617/7); H - cocoon (paratype MACN-Pa No. 617/8); I - cross-section of mature proglottid at level of ovary. Abbreviations: cs - cirrus sac; esv - external seminal vesicle; mg - Mehlis' gland; o - ovary; oc - ovicapt; od - oviduct; ud - uteroduct; ut - uterus; vf - vitelline follicle; vg - vagina. 

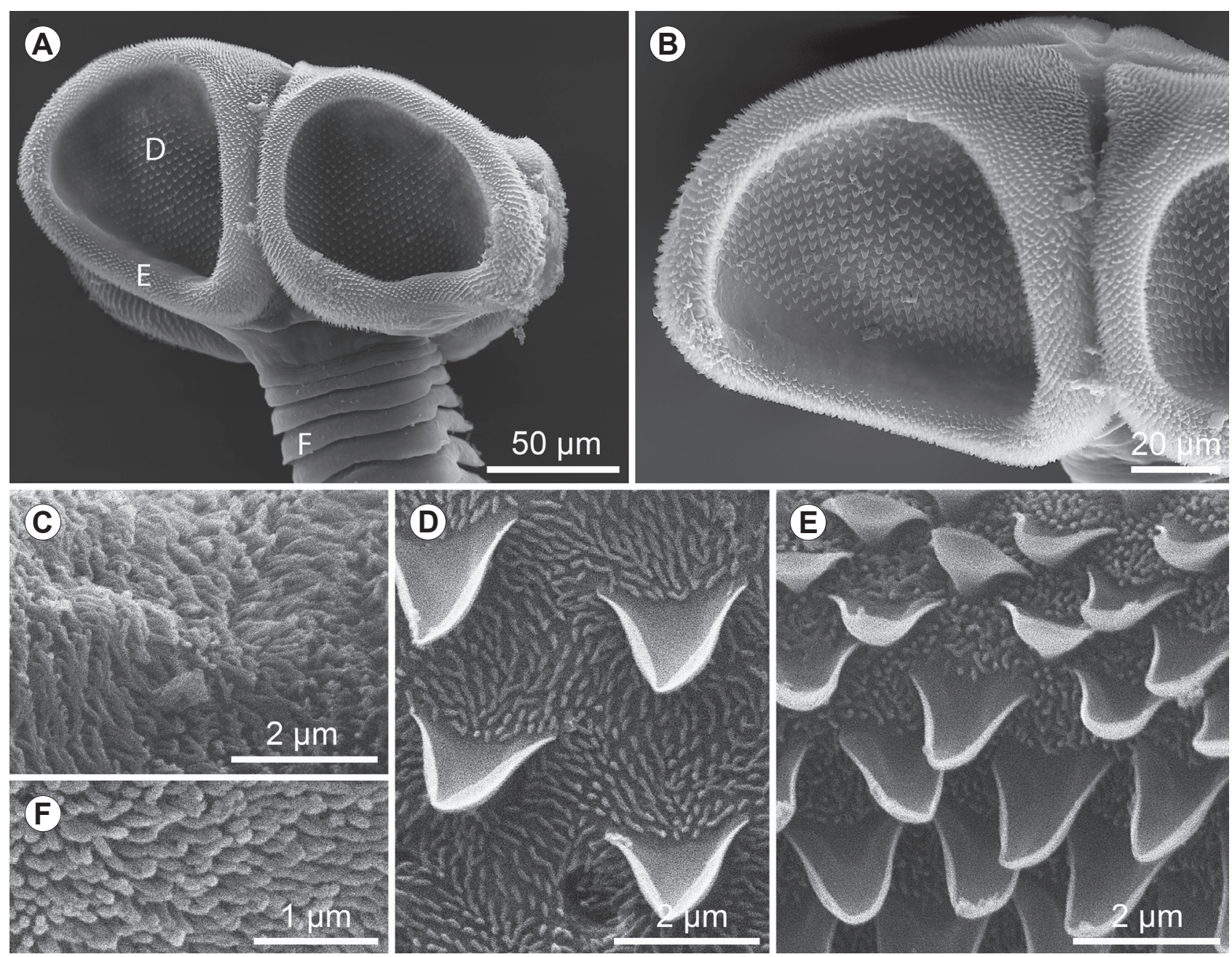

Fig. 4. Aberrapex sanmartini sp. n. from Myliobatis goodei Garman, scanning electron micrographs. A - scolex, small letters indicate locations of details shown in Fig. 4D-F; B - bothridiate acetabulum; C - surface of the apex of the scolex; D - distal acetabular surface; $\mathbf{E}$ - proximal acetabular surface; $\mathbf{F}$ - surface of an immature proglottid.

tes $225-350(271 \pm 45 ; 8)$ long, $180-330(239 \pm 44 ; 8)$ wide; terminal mature proglottids with degenerated testes $570-1,000(780 \pm 139 ; 12)$ long, 205- $330(259 \pm 38 ; 12)$ wide (Fig. 3D,G).

Testes $11-16(13 \pm 1 ; 8)$ in number, $30-55(41 \pm 7 ; 3 ; 5)$ long, $63-110(78 \pm 15 ; 3 ; 5)$ wide, arranged in $2-3$ irregular columns in dorsoventral view (Fig. 3G), extending from anterior margin of proglottid to anterior margin of ovary, slightly overlapping ovarian antiporal lobe, 1 row deep in cross-section, degenerated in terminal mature proglottid (Fig. 3B,D). Vas deferens in maturing proglottids in form of thin tube, extending from level of ootype to anterior margin of cirrus sac lateral in proglottid, enlarged to form external seminal vesicle in terminal mature proglottids with degenerated testes (Fig. 3B,C,E). External seminal vesicle extensive, saccate, extending almost medially in proglottid from level of ootype to level of anterior margin of cirrus sac (Fig. 3B,C,E). Internal seminal vesicle absent. Cirrus sac pyriform, slightly curved anteriorly in some specimens, 40-75 (62 $\pm 10 ; 3)$ long, 28-35 (32 \pm 3 ; 3) wide in maturing proglottids with testes; $65-130$ (94 $\pm 25 ; 4)$ long, 37-92 $(65 \pm 26$; 4$)$ wide in terminal mature proglot- tids with degenerated testes, containing coiled unarmed cirrus (Fig. 3E).

Ovary $\mathrm{H}$-shaped in dorsoventral view, tetralobed in cross-section (Fig. 3B,F,G,I), lobulated, 50-110 (78 \pm 23 ; 3) long, $100-145(126 \pm 15 ; 3)$ wide in maturing proglottids with testes; 155-275 (209 \pm 36 ; 5) long, 110-190 $(153 \pm 37 ; 5)$ wide in terminal mature proglottids with degenerated testes; ovarian isthmus at middle of ovary. Mehlis' gland well posterior to ovary, surrounded by vitelline follicles (Fig. 3B,C,F,G). Vagina slender, extending from ootype to genital atrium laterally in proglottid, opening into genital atrium posterior to cirrus sac (Fig. 3E,F). Genital pores lateral, irregularly alternating, 65-78\% $(72 \% \pm 6 \% ; 3)$ of proglottid length from posterior margin in mature proglottids with testes, $67-81 \%(76 \% \pm 4 \% ; 16)$ in terminal mature proglottids with degenerated testes.

Uterus saccate, extending along midline of proglottid from anterior margin of ovary to level of posterior margin of cirrus sac, curved porally (Fig. 3B,E,F). Uterine duct extending anteriorly from ootype, laterally to vas deferens and vagina, entering uterus at halfway between anterior margin of ovary and posterior margin of cirrus sac (Fig. 3C). Vi- 
telline follicles in 2 columns ( 1 dorsal, 1 ventral) on each lateral margin of proglottid, extending throughout entire proglottid, interrupted by cirrus sac and ovary (Fig. 3B-G); vitelline follicles $5-12(9 \pm 2 ; 3 ; 6)$ long, 15-35 (21 \pm 7 ; 3 ; 9) wide in mature proglottids with testes; 11-40 (19 \pm 5 ; 7 ; 21) long, 22-103 (39 \pm 8 ; 7; 21) wide in terminal mature proglottids with degenerated testes. Gravid detached proglottids $1,140-1,240(1,190 \pm 70 ; 2)$ long, 340-390 $(365 \pm 35 ; 2)$ wide (Fig. 3C). Eggs grouped in cocoons (Fig. 3C,H). Cocoons oval, 80-120 (98 $\pm 14 ; 1 ; 8)$ long, $55-78(63 \pm 8 ; 1 ; 8)$ wide, containing 16-22 (18 $\pm 2 ; 1 ; 10)$ eggs arranged in 3-4 columns (Fig. 3H). Unembryonate eggs $20-35(25 \pm 4 ; 1 ; 18)$ in diameter. Excretory ducts not observed.

Type host: Myliobatis goodei Garman, southern eagle ray (Myliobatiformes: Myliobatidae) (PD7-512b, PD7-514).

Site of infection: Spiral intestine.

Type locality: San Blas Bay off Carmen de Patagones, Buenos Aires Province $\left(40^{\circ} 42^{\prime} 58^{\prime \prime} \mathrm{S} ; 62^{\circ} 00^{\prime} 35^{\prime \prime} \mathrm{W}\right)$, Buenos Aires Province, Argentina (Fig. 1).

Specimens deposited: Holotype MACN-Pa No. 617/1 (entire worm) and 11 paratypes MACN-Pa No. 617/2-12 (4 entire worms, 2 strobilae, 4 detached proglottids, 1 preparation of cocoons in lactophenol); 2 paratypes IPCAS No. C-756/1-2 (2 entire worms); 2 paratypes LRP No. 9242, 9243 ( 2 entire worms). Additional specimens (whole mounts, histological sections, and specimens prepared for SEM) retained in the personal collection of Verónica Ivanov.

Prevalence : $22 \%$ (2 hosts infected out of 9 specimens examined).

E ty m o logy: This species is named after José de San Martín, one of the leaders of South America's successful struggle for independence from Spain.

Remarks. Aberrapex sanmartini sp. n. can be distinguished from $A$. senticosus, $A$. manjajiae and $A$. weipaensis in the microthrix pattern. Whereas $A$. sanmartini has hastate spinitriches covering the anterior $2 / 3$ of the distal acetabular surface, in $A$. manjajiae the hastate spinitriches are restricted to the central region of the acetabula, in A. senticosus they are covering the entire distal acetabular surface and $A$. weipaensis lacks hastate spinitriches on the distal acetabular surface altogether. In addition, $A$. sanmartini sp. n. differs from $A$. weipaensis by having postovarian vitelline follicles that are lacking in the latter species.

Whereas in A. sanmartini the uterus extends anteriorly to the level of the posterior margin of the cirrus sac, in A. weipaensis, A. senticosus and A. ludmilae the uterus extends well anterior to the cirrus sac. In this feature A. sanmartini sp. n. is most similar to A. manjajiae and $A$. arrhynchus. However, the uterine duct joins the uterus at its anterior-most point in $A$. manjajiae and $A$. arrhynchus, and enters the uterus at its midpoint in A. sanmartini. Additionally, A. sanmartini sp. n. possesses an external seminal vesicle that has not been observed in $A$. ludmilae and A. arrhynchus. Aberrapex sanmartini is also much shorter than A. ludmilae and A. arrhynchus (1.12-2.39 mm vs $3.33-4.93 \mathrm{~mm}$ and $3.01-4.66 \mathrm{~mm}$, respectively), has fewer proglottids (26-30 vs 37-45 and 42-52, respectively), fewer testes (11-16 vs 24-31 and 18-28, respectively), and a shorter scolex (100-150 $\mu \mathrm{m}$ long vs 160-190 $\mu \mathrm{m}$ and 165-205 $\mu \mathrm{m}$ long, respectively).

Aberrapex vitalemuttiorum $\mathrm{sp} . \mathrm{n}$.

Figs. 5, 6

ZooBank number for species:

urn:1sid:zoobank.org:act:E2D4A156-D7E7-4C87-9F63-5EA10727D1B4

Description (based on 19 specimens: 10 complete worms, 4 strobilae without scolex and 5 complete worms prepared for SEM). Worms 1.60-2.00 mm (1.80 $\mathrm{mm} \pm$ $0.17 \mathrm{~mm}$; 10) long, maximum width at terminal proglottid, euapolytic, $26-32(28 \pm 2 ; 10)$ proglottids per worm (Figs. 5D, 6A). Scolex 135-190 (157 \pm 15 ; 10) long, 200-240 (217 $\pm 14 ; 6)$ wide, consisting of 4 bothridiate acetabula; apical modification of scolex proper and apical organ absent (Figs. 5A, 6A,B). Acetabula cup-shaped, 105-135 (122 \pm 8 ; 6) long, 95-120 (104 \pm 8 ; 6) wide. Apex of scolex covered with acicular filitriches (Fig. 6F). Proximal and distal acetabular surface covered with hastate spinitriches and acicular filitriches (Fig. 6B-D,G); hastate spinitriches covering only anterior $2 / 3$ of distal acetabular surface (Fig. 6B,C); more densely arranged on proximal acetabular surface (Fig. 6D,G). Cephalic peduncle absent.

Proglottids covered with acicular to capilliform filitriches (Fig. 6E). Proglottids laciniate, with 4 laciniations (2 dorsal, 2 ventral) (Figs. 5A,C,D,F, 6A). Immature proglottids $25-31(27 \pm 2 ; 10)$ in number, initially wider than long, becoming longer than wide with maturity; posterior-most immature proglottid 195-320 (255 \pm 39 ; 12) long, $145-240(179 \pm 27 ; 12)$ wide (Figs. 5D, 6A). Mature proglottids 1-2 in number; terminal mature proglottids with testes 410-710 (556 $\pm 90 ; 12)$ long, 150-255 (191 \pm 30 ; 12) wide (Fig. 5F); terminal mature proglottid with most testes degenerated 890 long, 240 wide (observed in one worm) (Fig. 5C).

Testes 15-21 $(18 \pm 2 ; 12)$ in number, $20-63(45 \pm 10 ; 5$, 12) long, $33-85(62 \pm 12 ; 5 ; 12)$ wide, arranged in $2-3$ irregular columns in dorsoventral view, extending from anterior margin of proglottid to level of ovarian isthmus (Fig. 5F), 1 row deep in cross-section, degenerated in terminal fully mature proglottid (Figs. 5C). Vas deferens in maturing proglottids in form of thin tube, extending from level of ootype to anterior margin of cirrus sac lateral in proglottid, enlarged to form external seminal vesicle in terminal mature proglottids with degenerated testes (Fig. 5B,C,E). External seminal vesicle extensive, saccate, extending more or less lateral in proglottid from level of ootype to almost reaching anterior margin of proglottid (Fig. 5B,C). Internal seminal vesicle absent. Cirrus sac narrowly pyriform, slightly curved anteriorly, 25-55 (42 $\pm 10 ; 10)$ long, 18-39 $(27 \pm 6 ; 10)$ wide in maturing proglottids with testes; 110 long, 50 wide in terminal mature proglottid with degenerated testes, containing coiled unarmed cirrus (Fig. 5B,C).

Ovary H-shaped in dorsoventral view (Fig. 5C,E,F), tetralobed in cross-section, lobulated, 45-152 (91 $\pm 28 ; 12)$ long, $80-170(111 \pm 25 ; 12)$ wide in maturing proglottids with testes; 243 long, 145 wide in terminal mature proglottid with degenerated testes, ovarian isthmus slightly poste- 

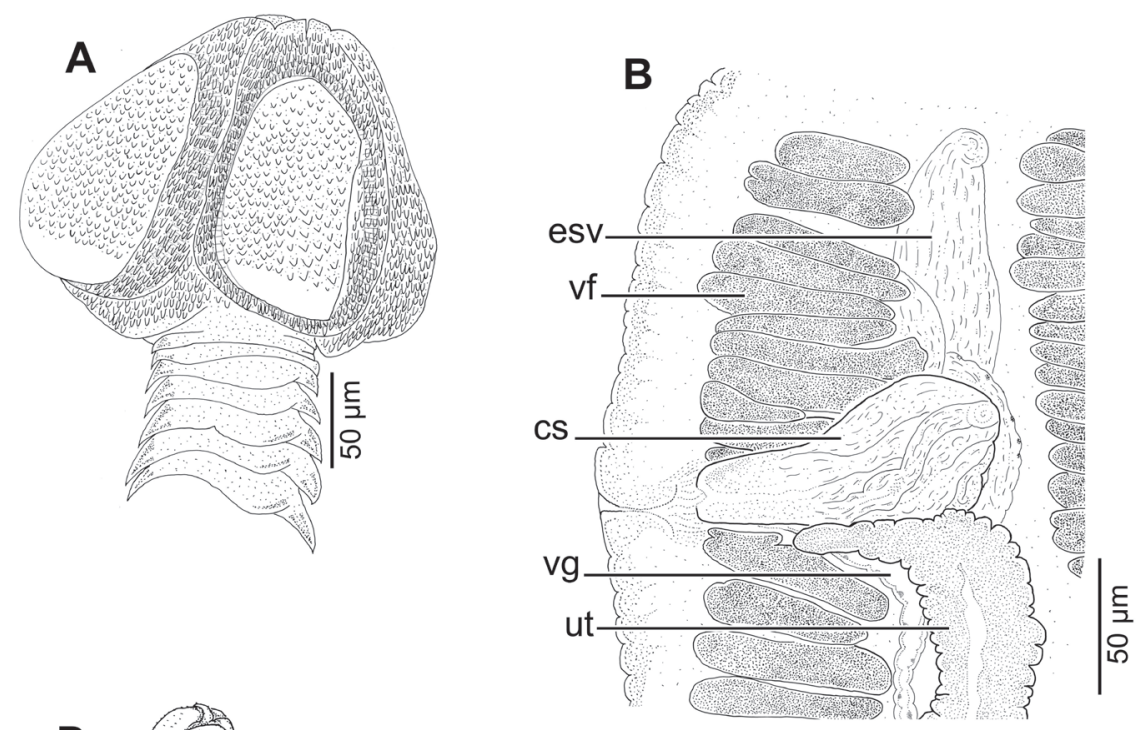

\section{C}
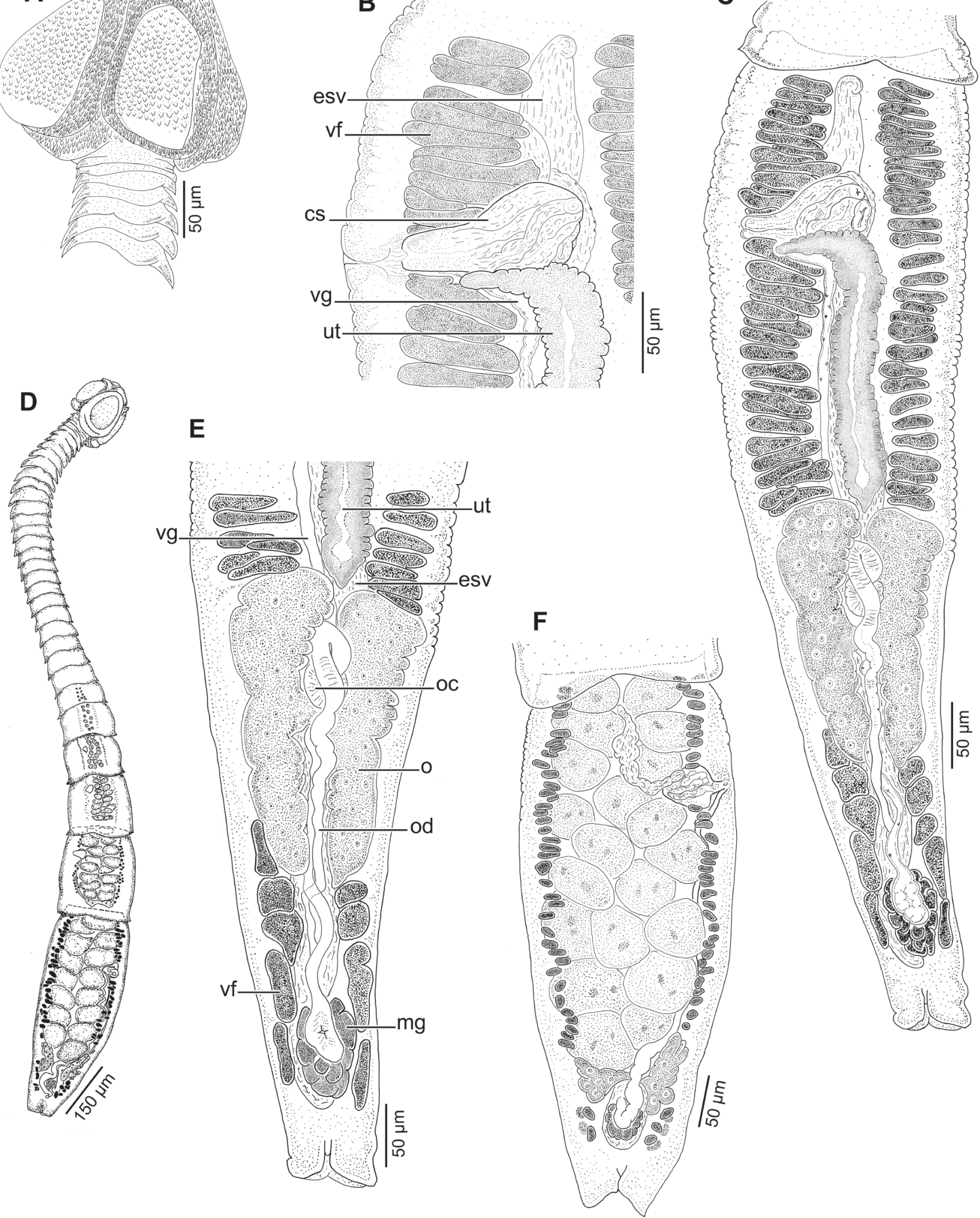

Fig. 5. Aberrapex vitalemuttiorum sp. n. from Myliobatis ridens Ruocco, Lucifora, Díaz de Astarloa, Mabragaña et Delpiani. A - scolex (paratype MACN-Pa No. 618/2); B - detail of terminal genitalia, ventral view (paratype MACN-Pa No. 618/3); C - terminal mature proglottid with degenerated testes, ventral view (paratype MACN-Pa No. 618/3); D - entire worm (holotype MACN-Pa No. 618/1); E - detail of ootype region, ventral view (paratype MACN-Pa No. 618/3); F - terminal mature proglottid with testes, ventral view (paratype MACN-Pa No. 618/4). Abbreviations: cs - cirrus sac; esv - external seminal vesicle; mg - Mehlis' gland; o - ovary; oc - ovicapt; od - oviduct; ut - uterus; vf - vitelline follicle; vg - vagina. 

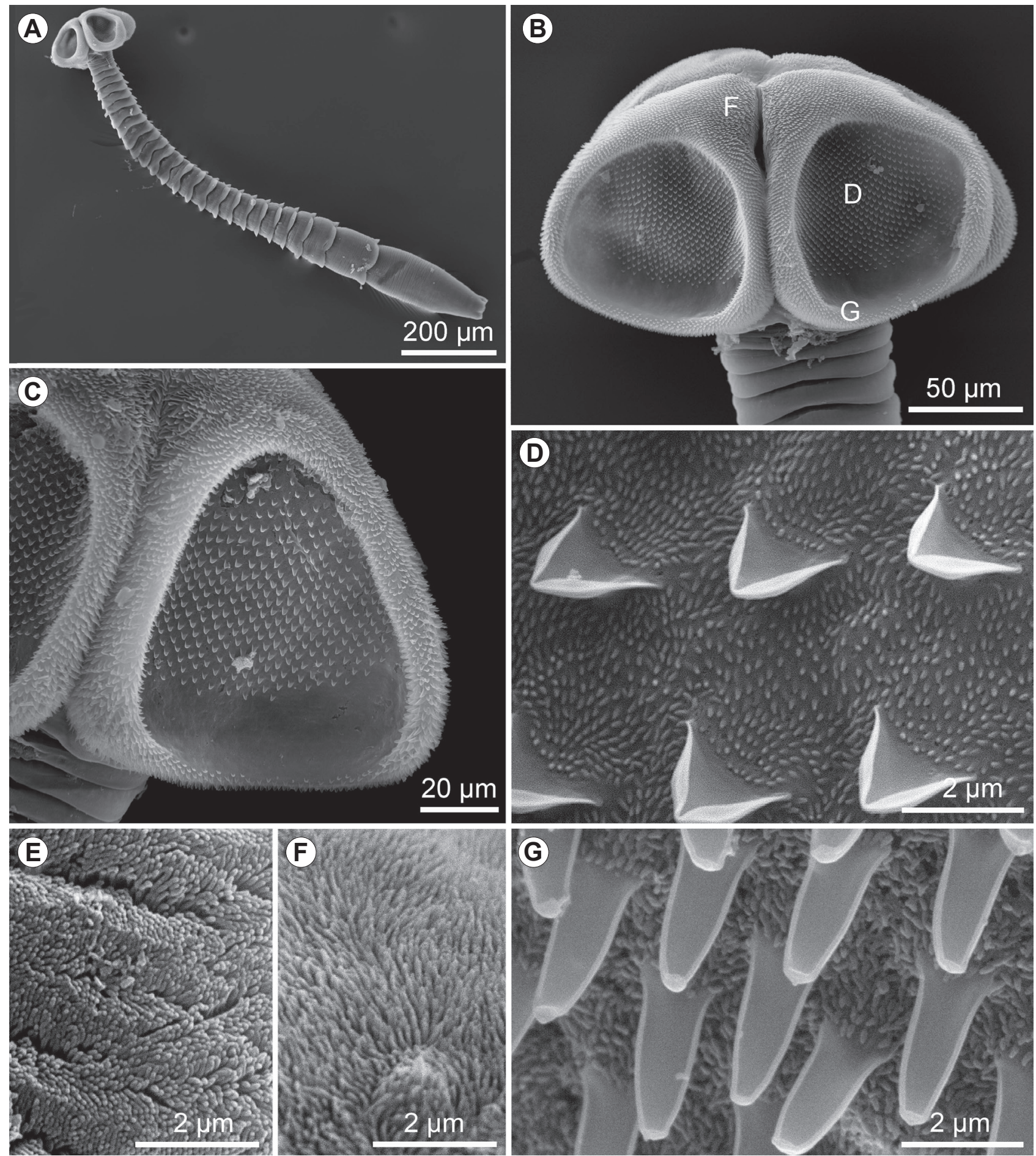

Fig. 6. Aberrapex vitalemuttiorum sp. n. from Myliobatis ridens Ruocco, Lucifora, Díaz de Astarloa, Mabragaña et Delpiani, scanning electron micrographs. A - entire worm; B - scolex, small letters indicate locations of details shown in Fig. 6D,F,G; C - bothridiate acetabulum; D - distal acetabular surface; $\mathbf{E}$ - surface of a mature proglottid; $\mathbf{F}$ - apex of the scolex; $\mathbf{G}$ - proximal acetabular surface.

rior to middle. Mehlis' gland posterior to ovary (Fig. 5E,F). Vagina slender, extending from ootype to genital atrium laterally in proglottid, opening into genital atrium posterior to cirrus sac (Fig. 5C,E). Genital pores lateral, irregularly alternating, $71-79 \%(76 \% \pm 2 \% ; 12)$ of proglottid length from posterior margin in mature proglottids with testes, $83 \%$ in terminal mature proglottid with degenerated testes.

Uterus saccate, extending along midline of proglottid from level of ootype to level of posterior margin of cirrus sac, curved porally at its anterior extremity (Fig. 5B,C,E). Uterine duct not observed. Vitelline follicles in 2 columns (1 dorsal, 1 ventral) on each lateral margin of proglottid, extending throughout entire proglottid, interrupted by cirrus sac and ovary (Fig. 5B,C,E,F); vitelline follicles 7-20 $(10 \pm 3 ; 12 ; 26)$ long, $8-30(16 \pm 6 ; 12 ; 26)$ wide in mature proglottids with testes; $8-12(10 \pm 2 ; 1 ; 4)$ long, $23-37$ $(28 \pm 5 ; 1 ; 4)$ wide in terminal mature proglottids with degenerated testes. Eggs and excretory ducts not observed. 
Type host: Myliobatis ridens Ruocco, Lucifora, Díaz de Astarloa, Mabragaña et Delpiani, shortnose eagle ray (Myliobatiformes: Myliobatidae).

Site of infection: Spiral intestine.

Type 1 ocality: Coastal waters off Villa Gesell (37²9'30"S; $56^{\circ} 45^{\prime} 00^{\prime \prime} \mathrm{W}$ ), Buenos Aires Province, Argentina (PD5-11) (Fig. 1).

Additional locality: Punta Negra, Necochea ( $\left.38^{\circ} 37^{\prime} 59^{\prime \prime} \mathrm{S} ; 58^{\circ} 51^{\prime} 58^{\prime \prime} \mathrm{W}\right)$, Buenos Aires Province, Argentina (FMPQ-76) (Fig. 1).

Specimens deposited: Holotype MACN-Pa No 618/1 (entire worm) and 9 paratypes MACN-Pa No. 618/2-10 (5 entire worms and 4 strobila); 2 paratypes IPCAS No. C-757/1-2 (entire worms); 2 paratypes LRP No. 9240, 9241 (entire worms). Additional specimens (whole mounts and specimens prepared for SEM) retained in the personal collection of Verónica Ivanov.

Prevale nce : $100 \%$ (2 hosts infected out of 2 specimens examined).

Etymology: This species is named in honour of the second author's parents, Graciela Mónica Vitale and Gabriel Alfredo Mutti.

Remarks. Whereas Aberrapex vitalemuttiorum sp. n. possesses a uterus that extends to the level of the posterior margin of the cirrus sac and curves porally, $A$. weipaensis, $A$. senticosus and $A$. ludmilae have a straight uterus extending anteriorly to the cirrus sac. Furthermore, $A$. vitalemuttiorum exhibits hastate spinitriches covering the anterior $2 / 3$ of the distal acetabular surface, while the hastate spinitriches on the distal acetabular surface in A. senticosus, $A$. manjajiae and $A$. weipaensis cover the entire surface, are restricted to its center, or entirely absent. Aberrapex vitalemuttiorum is shorter than $A$. ludmilae and A. arrhynchus (1.60-2.00 $\mathrm{mm}$ vs 3.33-4.93 $\mathrm{mm}$ and 3.01-4.66 $\mathrm{mm}$, respectively), and has fewer proglottids (26-32 vs 37-45 and 42-52, respectively). It can also be distinguished from A. sanmartini in having an external seminal vesicle that extends anteriorly beyond the cirrus sac instead of reaching the anterior margin of the cirrus sac.

\section{DISCUSSION}

As three new species are discovered in Aberrapex, several generic features require revision (Jensen 2001, 2005). For example, not all the species have hastate spinitriches covering the distal acetabular surface. In fact $A$. weipaensis lacks hastate spinitriches on that surface altogether (Koch et al. 2012). Also, vitelline follicles are either distributed along the entire length of the proglottid, interrupted only at the level of the genital pore and ovary or extend only to the anterior margin of the ovary, as in A. weipaensis (see Koch et al. 2012). The vas deferens is expanded to form an external seminal vesicle in most species (i.e. A. manjajiae, A. senticosus, A. weipaensis, A. vitalemuttiorum and A. sanmartini), extending anteriorly from the level of the ootype to the level of the cirrus sac (as in A. manjajiae, A. sanmartini and A. senticosus) (Jensen 2001, 2006; present study), or well anterior to the cirrus sac (as in A. vitalemuttiorum and A. weipaensis) (Koch et al. 2012; present study). Additionally, the testes can be distributed in two or three columns or in one single column as in A. manjajiae (see Jensen 2006).

As in some other lecanicephalideans, i.e. Eniochobothrium Shipley and Hornell, 1906, Paraberrapex Jensen, 2001 and Zanobatocestus Jensen, Mojica and Caira, 2014 (see Jensen et al. 2016), the eggs are packaged in cocoons as was described for $A$. sanmartini in the present study. Even if in the keys to lecanicephalidean families recently proposed by Jensen et al. (2016) the uterus is described as extending anterior to genital pore in Aberrapecidae, two different morphotypes can easily be distinguished among species in Aberrapex. The uterus is straight along the midline of the proglottid, extending from the level of the ootype to near the anterior margin of the proglottid (i.e. in A. senticosus and $A$. weipaensis) or to the level of anterior margin of cirrus sac (i.e. in A. ludmilae) (see Jensen 2001, Koch et al. 2012), whereas it stops short of the posterior margin of the cirrus sac and curves porally in the remaining species (i.e. A. arrhynchus, A. manjajiae, A. sanmartini and $A$. vitalemuttiorum). The position of the connection of the uterine duct to the uterus is also variable. In all the species with a straight uterus the uterine duct joins the uterus at the level of the genital pore (i.e. A. ludmilae and A. senticosus). In the species with porally curved uterus the uterine duct joins the uterus at its anterior end (i.e. A. arrhynchus) or more posteriorly (i.e. A. sanmartini). Also, in the recent diagnosis of Aberrapecidae the presence of an internal seminal vesicle is mentioned (Jensen et al. 2016), but this feature is lacking from all the descriptions of species in Aberrapex, the only genus in the family.

Therefore, the generic diagnosis of Aberrapex of Jensen et al. (2016) is emended as follows: scolex with four acetabula; apical modification of scolex proper and apical organ absent. Acetabula in form of oval, uniloculate bothridia. Cephalic peduncle absent. Worms euapolytic. Proglottids craspedote, laciniate or non-laciniate; immature proglottids of anterior strobila not laterally expanded; circumcortical longitudinal muscle bundles absent. Testes in 1-3 columns, one layer deep in cross-section, in single field. Vas deferens extending from level of Mehlis' gland to cirrus sac or well anterior to cirrus sac, expanded to form external seminal vesicle in some; internal seminal vesicle absent. Cirrus sac pyriform; cirrus unarmed, thin-walled. Genital pores lateral, alternating irregularly; genital atrium shallow. Ovary H-shaped in dorsoventral view, tetralobed in cross-section. Vagina lateral, opening into genital atrium posterior to cirrus sac. Seminal receptacle absent. Uterus saccate, medial, extending from ovarian isthmus to posterior margin of cirrus sac or to near anterior margin of proglottid. Vitellarium follicular; vitelline follicles in two lateral bands; each band consisting of 1-3 columns of follicles, extending entire length of proglottid and interrupted by cirrus sac and ovary, or extending only to anterior margin of ovary. Excretory vessels in single lateral pair. Eggs packaged in cocoons in one species.

Species of Aberrapex are parasites of myliobatiform stingrays, being especially diverse in the Myliobatidae. Members of this batoid family host six of the seven described species of Aberrapex (Jensen 2001, 2006, Koch et 
al. 2012), as well as Aberrapex n. sp. 1 sensu Jensen et al. (2016). All records of Aberrapex from rays collected from the coastal waters off Argentina and areas nearby are from species of Myliobatis, i.e. M. goodei and M. ridens. Considering that multiple species of Aberrapex can be found in a single host species (i.e. A. arrhynchus, A. ludmilae and A. sanmartini in $M$. goodei), it is likely that new species still remain to be discovered off Argentina.

None of the species of Aberrapex from M. goodei occurred in the same host individual nor in the same locality (Fig. 1). Thus, from north to south, A. arrhynchus was reported from Río de la Plata Estuary (Brooks et al. 1981), A. sanmartini from San Blas Bay and A. ludmilae from the San Matías Gulf. Biogeographically, these localities belong to different ecoregions in at least two provinces (i.e. Río de la Plata and Uruguay-Buenos Aires Shelf in the Warm Temperate South-western Atlantic Province, and the North Patagonian Gulfs in the Magellanic Province, respectively - Spalding et al. 2007) (Fig. 1). A similar pattern was found in trypanorhynchs from $M$. goodei (Menoret and Ivanov 2014, 2015). Specimens of $M$. goodei from the San Matías Gulf (Magellanic Province) were parasitised by Parachristianella damiani Menoret et Ivanov, 2014, while those from off Necochea (Warm Temperate South-western Atlantic Province) hosted Mecistobothrium oblongum Menoret et Ivanov, 2015.

Despite the wide distribution of $M$. goodei along the western coast of the Atlantic Ocean, from South Carolina, USA $\left(36^{\circ} \mathrm{N}\right)$ to Santa Cruz, Argentina $\left(46^{\circ} \mathrm{S}\right.$ ) (Cousseau et al. 2007), the specimens show locally distinctive cestode faunas, which are correlated with well-defined biogeographic regions. Moreover, the geographic area where specimens of $M$. goode $i$ were parasitised by $A$. sanmarti$n i$ and $M$. oblongum has been identified as a mating and nursery area for M. goodei (see Molina and López Cazorla 2015), where juveniles live for a year and adults spend the spring and summer every year. It might be possible that specimens of $M$. goodei become infected with these tapeworms while feeding in this sheltered area. If this pattern holds it would be expected that the area of the San Matías Gulf is also a mating and nursery area for $M$. goodei, where they become infected with $A$. ludmilae and $P$. damiani. In fact, the San Matías Gulf is an isolated coastal basin, which has oceanographic conditions differing markedly from those on the continental shelf (Piola and Rivas 1997). Some ichthyological and parasitological studies suggest that the physical characteristics of this area are responsible of stock discreteness of species of the teleost fishes Merluccius Rafinesque and Percophis brasiliensis Quoy et Gaimard (see Di Giácomo et al. 1993, Braicovich and Timi 2008).

While the specimens of $M$. goodei examined in this study were found to host two new species of Aberrapex, none of the specimens were found to host the third species of Aberrapex known from this host species (i.e. A. arrhynchus). Given that the type locality is the Río de La Plata
Estuary near Montevideo (Uruguay), the absence of $A$. arrhynchus from rays off Argentina might reinforced the idea of species of Aberrapex being more regionally distributed along the southern Atlantic shelf. Alternatively, there exist some doubts as to the identity of the type host of $A$. arrhynchus. As early as 1989, evidence mounted to suggest that a species similar to $M$. goodei occurred sympatrically with M. goodei of Buenos Aires Province and southern Brazil (Levy and Conceiçao 1989, Vooren 1997, Cousseau et al. 2007). This taxon was formally described as $M$. ridens by Ruocco et al. (2012).

There are currently three species of Myliobatis described inhabiting the water surrounding the type locality of $A$. arrhynchus (i.e. M. goodei, M. ridens and $M$. freminvillei) (see Cousseau et al. 2010, Ruocco et al. 2012); any of them could actually be the true type host of $A$. arrhynchus.

All the specimens of $M$. ridens examined in this study were caught in the same area (off Villa Gesell and Necochea in Uruguay-Buenos Aires Shelf ecoregion) and all resulted infected with the same species of Aberrapex, $A$. vitalemuttiorum (Fig. 1). It would be interesting to be able to examine specimens of $M$. ridens from elsewhere in its range of distribution (southern Brazil and Argentina), to investigate whether the tapeworms of $M$. ridens potentially show the same geographic pattern observed in M. goodei, given that both species share breeding areas (Araújo et al. 2016).

Acknowledgements. We are grateful to Juan M. Díaz de Astarloa, Ezequiel Mabragaña and Matías Delpiani from Laboratorio de Biotaxonomía Morfológica y Molecular de Peces (Universidad Nacional de Mar del Plata - CONICET) for their help in the identification of hosts collected on board of the RV 'Puerto Deseado'. We would also like to thank Gustavo Chiaramonte, who made laboratory facilities at the Estación Hidrobiológica Quequén, Museo Argentino de Ciencias Naturales - CONICET available to us, and Jorge Pérez Comesaña and Leonardo Tamini for their invaluable help in the field. Special thanks are due to Alejandro Martínez (Alex) from IBBEA (CONICET - UBA) for his invaluable help in the field and by sorting material in the lab, and to Ariadna Battista for assistance with cross-sections. We are also grateful to Eric Hoberg (USDA, ARS, Maryland, USA), Scott Gardner (HWML, Lincoln, Nebraska, USA) and Anna Phillips (NMNH, Washington, D.C., USA), who kindly made the type specimens of Discobothrium arrhynchum available to us. We also thank Consejo Nacional de Investigaciones Científicas y Técnicas (CONICET) for giving us the chance to work on board the Oceanographic Vessel 'Puerto Deseado' - CONICET. This work has been funded by grants UBACyT 20020130100617BA (2014-2017) from Universidad de Buenos Aires (Argentina), PIP No. 236 from CONICET and PICT 2014-2358 (2015-2018) from Agencia Nacional de Promoción Científica y Tecnológica (Argentina) to VAI; and Lerner Gray Memorial Fund for Marine Research (2015) from the American Museum of Natural History (USA) to AM. This study was conducted under collecting permits No. 39 and No. 260 from the Dirección Provincial de Pesca-Ministerio de Asuntos Agrarios de la Provincia de Buenos Aires, Argentina. 


\section{REFERENCES}

Araújo P.R., Oddone M.C., Velasco G. 2016: Reproductive biology of the stingrays, Myliobatis goodei and Myliobatis ridens (Chondrichthyes: Myliobatidae), in southern Brazil. J. Fish Biol. 89: 1043-1067.

Braicovich P.E., Timi J.T. 2008: Parasites as biological tags for stock discrimination of the Brazilian flathead Percophis brasiliensis in the south-west Atlantic. J. Fish Biol. 73: 557-571.

Brooks D.R., Mayes M.A., Thorson T.B. 1981: Cestodes parasites in Myliobatis goodei Garman (Myliobatidae, Myliobatiformes) from Río de la Plata, Uruguay, with a summary of cestodes collected from South American elasmobranch during 1975-1979. Proc. Biol. Soc. Wash. 93: 1239-1252.

Caira J.N., Jensen K. 2014: A digest of elasmobranch tapeworms. J. Parasitol. 100: 373-391.

Chervy L. 2009: Unified terminology for cestode microtriches: a proposal from the International Workshops on Cestode Systematics in 2002-2008. Folia Parasitol. 56: 199-230.

Clopton R.E. 2004: Standard nomenclature and metrics of plane shapes for use in gregarine taxonomy. Comp. Parasitol. 71: 130140.

Cousseau M.B., Degeneri M.A., Figueroa D.E. 2010: Fishes. In: M.B. Cousseau (Ed.), Fishes, crustaceans and molluscs of the Southwest Atlantic, between $34^{\circ} \mathrm{S}$ and $55^{\circ} \mathrm{S}$, with indication of important fishing species. Instituto Nacional de Investigación y Desarrollo Pesquero. Informe Técnico 5, pp. 1-64.

Cousseau M.B., Figueroa D.E., Díaz de Astarloa J.M., MaBRagaña E., Lucifora L.O. 2007: Rayas, Chuchos y Otros Batoideos del Atlántico Sudoccidental. Instituto Nacional de Investigación y Desarrollo Pesquero, Mar del Plata, 102 pp.

Di Giácomo E.E., Calvo J., Perier M.R., Morriconi E. 1993 Spawning aggregations of Merluccius hubbsi in Patagonian waters: evidence for a single stock? Fish. Res. 16: 9-16.

Ivanov V.A., CAMPBEll R.A. 1998: Echinobothrium megacanthum sp. n. (Cestoda: Diphyllidea) from the eagle ray Myliobatis goodei (Chondrichthyes: Rajoidei) from the Patagonian shelf of Argentina. Folia Parasitol. 45: 225-229.

JENSEN K. 2001: Four new genera and five new species of lecanicephalideans (Cestoda: Lecanicephalidea) from elasmobranchs in the Gulf of California, Mexico. J. Parasitol. 87: 845-861.

Jensen K. 2005: Tapeworms of elasmobranchs (Part I). A monograph on the Lecanicephalidea (Platyhelminthes, Cestoda). Bull. Univ. Nebr. State Mus. 18: 1-241.

Jensen K. 2006: A new species of Aberrapex Jensen, 2001 (Cestoda: Lecanicephalidea) from Taeniura lymma (Forsskål) (Myliobatiformes: Dasyatidae) from off Sabah, Malaysia. Syst. Parasitol. 64: 117-123.

Jensen K., Caira J.N., Cielocha J.J., Littlewood D.T., WAESCHENBACH A. 2016: When proglottids and scoleces conflict: phylogenetic relationships and a family-level classification of the Lecanicephalidea (Platyhelminthes: Cestoda). Int. J. Parasitol. 46: 291-310.

Koch K.R., Jensen K., CAIRA J.N. 2012: Three new genera and six new species of lecanicephalideans (Cestoda) from eagle rays of the genus Aetomylaeus (Myliobatiformes: Myliobatidae) from northern Australia and Borneo. J. Parasitol. 98: 175-198.

LeVy J.A., ConceiçAo M.B. 1989: Biochemical evidences for two sibling species of genus Myliobatis (Chondrichthyes: Myliobatidae) in South Brazil. Comp. Biochem. Physiol. 94: 687-690.

Linton E. 1890: Notes on Entozoa of marine fishes of New England, with descriptions of several new species. Part II. U. S. Comm. Fish and Fisheries. Part XV. Rep. Comm. 1887, 15: $718-899$.

Menoret A., Ivanov V.A. 2014: Eutetrarhynchid trypanorhynchs (Cestoda) from elasmobranchs off Argentina, including the description of Dollfusiella taminii sp. n. and Parachristianella damiani sp. n., and amended description of Dollfusiella vooremi (São Celemente et Gomes, 1989). Folia Parasitol. 61: 411-431.

Menoret A., Ivanov V.A. 2015: Trypanorhynch cestodes (Eutetrarhynchidae) from batoids along the coast of Argentina, including the description of new species in Dollfusiella Campbell et Beveridge, 1994 and Mecistobothrium Heinz et Dailey, 1974. Folia Parasitol. 62: 058.

Molina J.M., López Cazorla A. 2015: Biology of Myliobatis goodei (Springer, 1939), a widely distributed eagle ray, caught in northern Patagonia. J. Sea. Res. 95: 106-114.

Mutti L.D., Ivanov V.A. 2016: A new species of Paraberrapex Jensen, 2001 (Cestoda: Lecanicephalidea) from Squatina guggenheim Marini, 1936 (Squatiniformes: Squatinidae) off Argentina. Folia Parasitol. 63: 007.

Piola A.R., Rivas A.L. 1997: Corrientes en la plataforma continental. In: E. Boschi (Ed.), El Mar Argentino y sus Recursos Pesqueros. Instituto Nacional de Investigación y Desarrollo Pesquero, Mar del Plata, pp. 119-132.

Ruocco N.L., Lucifora L.O., Díaz de Astarloa J.M.D., MaBRAGaña E., Delpiani S.M. 2012: Morphology and DNA barcoding reveal a new species of eagle ray from the southwestern Atlantic: Myliobatis ridens sp. nov. (Chondrichthyes: Myliobatiformes: Myliobatidae). Zool. Stud. 51: 862-873.

Spalding M.S., Fox H.E., Allen G.R., Davidson D., Ferdaña Z.A., Finlayson M., Halpern B.S., Jorge M.A., Lombana A., Lourie S.A., Martin K.D., McManus E., Molnar J., Recchia C., Robertson, J. 2007: Marine ecoregions of the world: a bioregionalization of coastal and shelf areas. Bioscience 57: 573-583.

Vooren C.M. 1997: Demersal elasmobranchs. In: U. Seeliger, C. Odebrecht and J.P. Castello (Eds.), Subtropical Convergence Environment: the Coast and the Sea in the Southwestern Atlantic. Springer-Verlag, Berlin, pp. 141-146. 